\title{
Percival Pollard: The Iowa Connection
}

\section{ORA T. DUNSMORE}

When the Pollard family, consisting of Mr. and Mrs. Joseph P. Pollard and son Percival, came to Iowa, it was another instance of the widening ripple of English tradition lapping gently at the rich black loam of the Middle West and leaving a permanent impression.

They did not come with any flourish of trumpets. Indeed, their arrival in Washington, Iowa, at that time a country hamlet of two thousand, was totally ignored by the local press. From the obituary items at the death of Mr. Joseph Pollard, we learn that they came to Iowa from Texas, where the elder Mr. Pollard had been engaged in farming. The only chronicler of their advent is a local woman who was a fellow-passenger. She says it was so extremely difficult to keep her eyes away from the unique trio-the large, bearded man; the tall. slender boy with a hectic flush; the oddly dressed woman with the foreign accent-that she was never able to be at ease in their presence when she later came to know them, for she was always conscious of her unpardonable staring on that occasion. It was as if three people had stepped out of the pages of Dickens.

It is to be inferred that the agricultural episode in Texas was not of a particularly felicitous nature, for the Pollards were definitely at a low financial ebb when they came to Iowa. They took a small, unpretentious dwelling at the edge of town where they "got along." Among other makeshifts, to keep the pot boiling, they sold milk, and Percy delivered it in tin pails, with a jockey cap perched on his high, pale forehead. If he was accused of being parsimonious in his later

[Editor's note: Mrs. Dunsmore's article constitutes a chapter, slightly edited, from A Study of Percival Pollard, an unpublished thesis written for her Master of Arts degree in the Department of English, The University of Iowa, June, 1932. Grateful acknowledgment is made to Mrs. Dunsmore for permission to use this material. Mrs. Dunsmore has recently presented to the University of Iowa Libraries her letters from Rupert Hughes, H. L. Mencken, and Joseph P. Pollard IV, son of Percival Pollard, which she received in response to her inquiries at the time she was engaged in the preparation of her thesis.-F.S.H.] 
years, it is rather to his credit that the experience of his youth did not forsake him when he was able to gratify his personal whims, and that he chose to live modestly rather than ostentatiously when his fortunes mended.

Joseph Percival Pollard III, the subject of our sketch, was born in Greifswald, Pomerania, on January 29, 1869. His mother, Marie Pistor, was German, an opera singer, and his father was English, from Newcastle-upon-Tyne. The latter was, at that time, traveling on the continent in the interests of the family grain-brokerage business. The mother died ${ }^{l}$ when Percy was quite young, and we find the father marrying again, in 1877, another German woman, Anna von Homeyer. No doubt the aftermath of the Franco-Prussian War and the unsettled economic conditions were affecting the grain business, for in 1885 the Pollards emigrated to Texas, where the second Mrs. Pollard had relatives. It may be remembered that this was the era in which thousands of Englishmen came to the States with the idea of recouping their shattered fortunes in the cattle business. Mr. Joseph Pollard, Jr., was not the exception, and two years later he came to Iowa. Thus far no reason is known for his choice of location except for its remoteness and anonymity. The Englishman "on his uppers" is like the wounded lion and, in distress, does not seek his own kind.

Things began to improve for the Pollards shortly after they came to Iowa. In the Washington County Press, January 25, 1888, the following advertisement makes its appearance and does so continuously till the death of the advertiser in 1902:

Joseph Pollard, Jr.

Loans money at lowest rates, furnishes

Abstracts of Title to all Property quickly, and sells and exchanges Land and Real Estate in all States. Office, N.W. Corner of Square, Washington.

No doubt the money to loan was fiction, but Mr. Joseph Pollard, Jr., did commence an abstract business that furnished a comfortable livelihood and won him an enviable reputation for infallibility in the matter of clearing titles.

In an agricultural community, Mrs. Pollard began to educate the natives in the poultry business. Everyone kept chickens in those days,

I [Other sources indicate that the parents were divorced. See Douglas C. Stenerson in his Introduction, p. vi, to the reprinted edition of Percival Pollard, Their Day in Court (New York and London: Johnson Reprint Corporation, 1969).-Ed.] 
but pedigreed fowls were unknown. Mrs. Pollard imported them and charged fancy prices for settings of their eggs. Her surplus went to the market, but when crafty souls attempted to get settings by purchasing her eggs at store prices, their chagrined hens sat in vain until someone discovered that the Pollard eggs sold at the store were punctured to admit air and render them infertile. While she called her chickens her "birds" and made pets of them, still, from time to time, such notices as this of April 1, 1891, appeared in the local newspaper:

Mrs. Pollard, Washington, has two pairs White Cochins, one pen Plymouth Rocks, and some Brahmas for sale, to make room for more imported stock.

With her poultry, her horses, and her foreign habit of waiting on her men and thinking of their comfort in everything first, she was slow to become acquainted with the townspeople in more than a formal or casual relationship.

The first social overtures and contacts cane through Percy. Boylike, he found his friends. Where the parents kept aloof with their problems, he made acquaintances among his own kind and was so adaptable that his chums failed to realize his varied background of birth, experience, and education. His formal schooling was ended by the time he came to Iowa, but it had included training both on the continent and in England, where he attended Eastburne College in Sussex. Percy engaged in the activities of his little clique of intimates, conforming to their habits and pursuits. He sang high tenor in the male quartet coached by Professor Mills. The boys were invited to his home for an occasional social gathering in a novel and distinctly English atmosphere, where wine was served, to their surprise and delight, for the local trend was toward prohibition. He even enrolled in the Academy for a course in shorthand offered by an itinerant instructor, Professor Markum.

This business training led to his first employment, in 1890, in the railroad offices in St. Joseph, Missouri. He was loyal to his Washington friends and found a position for one of them, Orville Elder, in the same office in which he was employed. This friendship was continued, although with interruptions, to the time of his death. From the railroad office, he went into journalistic work on the St. Joseph Daily News. Evidently the writing-bee had been buzzing, for it was about this time that the weekly "literary" papers, which were flourishing then, began to carry sketches by Percival Pollard.

It was at this time that the editor of the Washington County Press penetrated the British exterior and found the Pollards first-rate copy. 
On May 6, 1891, he informs us that "Percy Pollard is editor of Light, a comic Chicago weekly, a la Puck and Judge." The editor of the Press, Mr. Howard A. Burrell, was tremendously concerned with the literary developments of the day. He had an original, personal style in the tone of his newspaper and took a vicarious interest in the development of a man connected with Washington. As far as he was able, he took pains to keep the readers of his paper in touch with the Pollards. This is one of the rare bits to illustrate:

July 12,1893 . One of the coolest things was the committee's asking our esteemed citizen, Mr. Pollard, an Englishman, to donate to the 4th of July fund. But he gave $\$ 1-$ they wanted $\$ 5$, and like everybody else, he no doubt thinks it was a poor show for the money.

An item of August 23, 1893:

Percy Pollard of the Chicago Figaro was in town last week, happy in his work.

By this time the Pollard career was well under way. Percival was a coeditor of the Chicago Figaro, a monthly literary collection of sketches, reviews, and the usual "precious" items for an esoteric audience, and he had established many journalistic contacts with men of prominence in both journalism and literature. An interesting contact was made this year with none other than the eccentric "Bitter Bierce." Just where and how they first met is not definitely known, but it would appear that the following letter, apparently in reply to some query of Pollard's, initiated the friendship:

Dear Mr. Pollard, Berkeley, Cal. July 20, 1893

Your question about the Caswell Company I am unable to answer definitely. Mrs. Atherton sends me a note from her latest publisher (Tait) in which he says he "thinks" the affairs of the Company are now conducted by a receiver. I am myself too much disgusted to inquire, or very greatly care. The failure of four publishers out of five in one year rather takes away my interest in the tribe. Schulte, the U. S. Book Company, a private person named Langton (who undertook my Black Beetles in Amber) and now the Caswells-that is a fairly good array of notches in my riflestock, is it not? I had read about $m_{4}$ of the proof of my new book 
of yarns when the trouble occurred-the proofs stopped coming and that's all I know.

You mistake about my mentioning you to Charles Edwin Markham; I do not know him personally. I suppose he read what I wrote of you.

I trust you will succeed in your Figaro venture-newspapering is, after all, our only permanent hold upon our bone, even if the meat upon the bone is not altogether to our liking.

Yes, I get Belford's ${ }^{2}$ and Figaro regularly, and thank you very much for them. Would you mind taking the trouble to alter the address to the Examiner office San Francisco, until I am "settled"? Ill health has compelled me to be rather a nomad lately. I did not know Belford's was in trouble and am sorry to learn it.

Enclosed is a slip from the Oakland Saturday Press (Cal.) of the 17th July.

Success attend you, Ambrose Bierce ${ }^{3}$

That Pollard's correspondence was calculated to bring results is found in a letter from Bierce written later the same year. While he was sincerely admiring Bierce's work, it was not with the silent, shy reverence of a novice. He was conferring favors of time and effort to bring about personal relations and intimacies-as close as a reserved person ever desires them. Neither Pollard nor Bierce would have suffered a Damon-and-Pythias devotion; it would have been intolerable to either of them, quite as much so to Pollard as to Bierce. But the following letter does make evident that Pollard was concerned with cementing his acquaintance with Bierce by rendering a gratuitous service:

Berkeley, Cal.

Oct. 18, 1893

Dear Mr. Pollard,

I am greatly obliged to you for your kindness in ascertaining about the Schulte matter. But please do not take any further trouble about it, as I can learn what else I want to know without bothering so busy a man as you probably are.

I'm glad you do not think badly of Schulte, for I have tried to

2 Belford's Monthly Review, of which Pollard was literary editor from 1892 until its suspension in 1893.

3 [This and the following two letters were loaned to Mrs. Dunsmore by Joseph P. Pollard IV, son of Percival Pollard, in 1932. Present location of the letters is unknown.-Ed.] 
think well of him myself, all through-albeit the failure hit me in a tender place, for I have a weakness for "The Monk and the Hangman's Daughter," and think it would have sold. I'm handicapped, too, with a rascally collaborator whom I recently had to thrash for lying and cheating.

Mrs. Atherton writes me she is off to the Fair, so you'll doubtless see her, or have seen her already. You'll find her a truehearted creature, and clever withal.

I have seen no more of Markham, but had a note from him the other day.

Prosperity attend thee.

Ambrose Bierce

This letter is of some significance, for it gives another view of the quarrel between Adolphe de Castro and Bierce regarding their dealings over the collaboration on The Monk and the Hangman's Daughter. It is firsthand testimony of Bierce's side of the story, while de Castro's may be found in his book on Bierce. ${ }^{4}$

There is some reason to believe that at this time, or a little earlier, Pollard may have visited San Francisco and met Bierce and others of the literary coterie of that place; but so far it is merely conjecture and unsupported by record. His acquaintance with the West and the writers from the West seems to be too complete to be accounted for by a few meetings and casual correspondence.

The Washington County Press for May 27, 1896, reveals the interesting news that "the recent death of his grandmother gives Percy Pollard a plethoric legacy, it is reported." A careful perusal of the newspapers that followed this report reveals no denial; there are, in fact, two reasons for believing that the item was correct: first, the elder Mr. Pollard and the editor of the newspaper were intimates and, second, the former would have insisted upon a retraction, regardless of friendship for the editor, had the statement been inaccurate. Then, too, the size of the estate to which Walter Neale testifies at Percival Pollard's death 5 could hardly have been accounted for by his literary and journalistic earnings.

Whether it was a "plethoric" or merely a moderate estate that he inherited, Pollard's work was not halted by this windfall. That he had

4 Adolphe Danziger de Castro, Portrait of Ambrose Bierce (New York: The Century Co., 1929), passim.

5 Walter Neale, Life of Ambrose Bierce (New York: Walter Neale, 1929), p. 252 , states that "Pollard never felt the need for money, and his estate was valued at considerably more than $\$ 100,000$ when he died." 
sincerely and genuinely dedicated himself to literature is most forcefully shown by the fact that, with the acquisition of money, his literary activities increased rather than diminished.

He became concerned with the fortunes of The Echo, another of the "arty" publications, and thus met Walter Blackburn Harte, on whom he showers the highest praise in his volume of criticism, Their Day in Court. ${ }^{6}$ A letter from Miss Amy Leslie ${ }^{7}$ is a testimony to the type of publication and another testimony to Pollard's methods of making acquaintances.

Mr. Percival Pollard

Sunday Dec. 8th, 1895

My Dear Sir:

I have but one vigorous indestructible quality-I never do anything I intend to do. When I instantly and vehemently made up my mind last summer to indite profuse gratitude at you for the gift of The Echo's first folio, it was as good as settled that my thanks should reach you with the snows. Yesterday The Echo's leaves arrived from the binders in a pretty soft gray leather wrap and so complete and beautiful a collection of affiche in miniature is, I assure you, most treasurable. The Echo is always delightful not only as an indicative perpetuation of that phase of art most fashionable, but of wit, rich, true, and vivacious. I am grateful for its chic and brilliancy and its royal impudence directed against the cheap shams. Mr. Harte has at last crept out of his curious shell, loaded with pearls-not that I liken the giant Walter B. unto a N. Y. count, but he is a creature of jewels. Mr. Harte is one of my especial idols and I know he is a friend of yours. The Fly Leaf is like him, isn't it? I want to cheat James L. Ford out of first thanks to you for the notice of his new book. Jimmie is a relation of mine and more than that, a pal-since childhood. He will be grateful for the notice in The Echo.

Will you tell me, Mr. Pollard, about "The Cape of Storms"? Is it to fill out your heartiest anticipations and all that? I am interested in the posted exposition and beg you will command me if I can be of any service to your interest or The Echo.

Sincerely, Amy Leslie

\footnotetext{
6 Percival Pollard, Their Day in Court (New York: Neale Publishing Co., 1909). [Harte (1867-1898) was the author of Meditations in Motley (1894) and assistant editor of the New England Magazine,-Ed.]

7 [Amy Leslie (Mrs. Lillie West Brown-Buck) was an opera singer and a longtime drama critic for the Chicago Daily News. She was a native of West Burlington, Iowa.-Ed.]
} 
Pollard himself calls The Echo "a periodical ... to foster the cult of the artistic poster; despite much exaggeration, a definite improvement in the art of the pictured advertisement was gained."8 The Fly Leaf was a pamphlet issued by Harte which Elbert Hubbard finally persuaded him to merge with his own. It was an unfortunate merger, for it killed Harte's paper.

The vitality that Pollard was spending in his calling was tremendous. There was nothing but work in his program at this time. His activities are chronicled in the Washington County Press:

November 4, 1895. The Chicago News says Richard Mansfield, the actor, has engaged Percival Pollard as his press agent vice the Slocums, and another Pollard periodical is to be issued monthly in N. Y.

December 16, 1896. Percival Pollard sends us the September number of The Clack Book, an odd-shaped, queer-typed, illustrated monthly, cute in form. He has a graceful sketch, "In the Cave of Dreams," telling what befalls the average young fellow as he goes down the hill to Avernus. Do they generally go to Avernus? We trust not.

December 30, 1896. Last Monday night, Percy Pollard's play, "A First Violin," was to have had its first night in N. Y. But Mansfield got mad at several in his troupe and threw it up.

Between the years 1893 and 1896, Pollard had withdrawn from Figaro, formed the connection with The Echo, free-lanced not a little, and written a novel, The Cape of Storms. He met and married his first wife, a young woman from Chicago, from whom he was later divorced. They visited Pollard's parents frequently, and their Iowa friends found them a most strikingly handsome couple, the ideal contrast of blond and brunette. The Press for January 12, 1898, jovially announces:

Percival Pollard is an author again, of a boy, brand new edition, illustrated but not indexed. Issued in Chicago the 6th. Shake!

October 26, 1898. Mrs. Percy Pollard and baby are here for the winter. The baby will be rocked in the cradle that rocked Octave Thanet.

8 Pollard, Their Day in Court, p. 377. 
March 23, 1898. Percy Pollard is sub-editor of Town Topics, the New York social paper, and is hard-worked but enjoys a handsome salary. He is also its dramatic critic. The last three days of the week he has more leisure and devotes it to writing for The Criterion, etc.

It was perhaps through The Criterion that Pollard first became widely known. A fellow Iowan, Rupert Hughes, was also one of its editors, and in a letter of March 6, 1932, to the writer, he refers to this episode in their converging careers:

I knew Percival Pollard quite well. He was writing for The Criterion from the first. I took a position as assistant editor and our relations were pleasant without ever being intimate. He wrote dramatic criticism, book reviews and essays. He was a tall, slender, poetic-looking man and it surprised me to know that he came from lowa.

The first editor of The Criterion was a Frenchman, Henri Dumay, who brought the paper to N. Y. from Saint Louis where he had been a professor of French. When he severed his connection, Pollard wrote also for his successor, Joseph J. C. Clarke. . . .

$\mathrm{He}$ had quite a high position as a critic in those days, but died young. He took the arts very seriously though he wrote with a light and extremely personal manner-as a sort of precursor of the George Jean Nathan school of intensely subjective pronouncement. $^{9}$

Walter Neale, in his Life of Ambrose Bierce, introduces us to the Pollard he knew, a profile which is at variance with the man as he was known to his contemporaries in the Middle West. Neale says:

Like Pooh-Bah, Percival Pollard was born sneering. Good! He was to find much to sneer at. All his life he sneered; sneering, he died. ${ }^{10}$

And:

But he was rarely more than an onlooker at any place where he met life. Taciturn, rather morose, suspicious of his associates; inordinately stingy; apparently without the slightest affection for

9 [Letter in Special Collections Department, University of Iowa Libraries.-Ed.] 10 Neale, Life of Ambrose Bierce, p. 243. 
any human being, caring only for Art and for things abstract; sullen; unable to see good in anything except in Art, holding, with Oscar Wilde and James McNeill Whistler, that Art is more important than Nature, higher than Nature, in every respect superior to Nature, that Art alone made life worth while-Percival Pollard concentrated such affections as he possessed on Art alone. A more uncompanionable associate than he could hardly be imaginedwhen morose and sullen. ${ }^{11}$

If Pollard did become the man pictured in this paragraph, it must have been after his removal to the East, because as a young man he had made many friends to whom he remained an ideal of affability and courtesy. In a featured sketch on the front page of The Weekly Outlook ("devoted to home and outing life, literature, art, music, and the drama"), published at Davenport, Iowa, in the issue of June 19, 1897, Pollard, in his final paragraph, is altogether foreign to the man described by Neale: "And I thank whatever gods there be . . that I have come, if perhaps only for a space, to the realization of that last, best desire of the dear Saint Robert Louis: Du lieber Gott-friends!" Perhaps the man did, like the chameleon, change the color of his personality with the years, although H. L. Mencken, in a letter to the present writer, comments:

It seems to me to be foolish to say that Pollard was embittered in his old age. I saw a good deal of him in his last years, and he was always in good humor, and full of optimistic plans for new books. In fact, he died with four or five such books blocked out. ${ }^{12}$

After accepting the position on the staff of Town Topics, Pollard was little known to his Iowa friends. The news of his divorce and remarriage was quite shocking to those who knew and admired his first wife. She, however, remained on the best of terms with her former husband's parents and, with their grandson, continued to visit them till the death of the elder Pollard in 1902. There may have been an estrangement between father and son over this affair, but it is more reasonable to believe it was the amount of work compelling him which kept Percival Pollard almost continuously in the East after accepting this position.

His second marriage occurred on January 22, 1899, and his perma-

11 lbid., p. 251.

12 [Letter dated April 25, 1932, in Special Collections Department, University of Iowa Libraries.-Ed.] 
nent home was finally made in Baltimore. He had a summer home in Connecticut where his friends-Bierce in particular-and even Orville Elder, the friend of his Iowa youth, visited him. He was continually making trips abroad to keep his readers abreast of the newest developments in the art of the continent, not only in literature but in music and painting as well.

The last ten years of his life were spent in such a diversified routine. The activity that motivated him was the self-flagellating zeal of the devotee. His work was about to come in for proper recognition when he was suddenly taken ill and died on December 17, 1911, at not quite forty-three years of age, without seeing his last volume of travel essays, which was published the day of his funeral.13

H. L. Mencken arranged Pollard's funeral ${ }^{14}$ and it was at the service, in the carriage going to the cemetery, that Mencken met Ambrose Bierce for the first time. It is said that Pollard was the one man with whom Bierce, who boasted that he had no friends, parted on friendly terms, and that was for the reason of Pollard's untimely death. Had Bierce known Pollard was to die, no doubt he would have effected a quarrel with him. As it stands, the two parted on the best of terms, and their friendship was the one amicable intimacy of Bierce's life, although it was interrupted by violent disagreements. Walter Neale is authority for the statement that Bierce felt Pollard's loss very keenly all the rest of his life. ${ }^{15}$

The notice of Pollard's death in Current Literature is titled "A Critic Too Far Ahead of His Time":

Almost unnoticed by the press there passed away the other day in Baltimore ... . one of America's greatest critics. . . . If Ambrose Bierce is, as he has been called, a writer with a vast "underground reputation," the same may be said of Pollard the critic. His fame was distinctly subterranean, but it extended over two continents. . . . We find few reviews of his books. Staid and pedantic publications have no word to say for Percival Pollard, living or dead. For sympathetic valuations of his work we must turn to English sources. "Percival Pollard," said Vanity Fair of Their Day in Court, "has written a book about books which carries the imprint of a big personality." "In Mr. Percival Pollard's volume," said

13 Percival Pollard, Vagabond Journeys (New York: Walter Neale, 1911).

14 "He died here in Baltimore, and I arranged his funeral. . . . The only other mourners were Ambrose Bierce, Walter Neale the publisher, and Mrs. Pollard." Letter to writer from H. L. Mencken, dated August 24 [193I]. [Letter now in Special Collections Department. University of Iowa Libraries.]

15 Neale, Life of Ambrose Bierce, p. 260. 
the London Academy, "we have quite the most remarkable and honestly intentioned book that has come out of America for many a day."16

Pollard is comparatively unknown today, not because his work was of little value but because there was so little recognition of it in his lifetime. His early death cut off a career that was just in its beginning.

There was sound reason for the validity of his literary judgment. In addition to personal qualifications, he had a wide experience in the mechanics of the publishing business in the United States and he was continually making trips abroad, where he kept in touch with modern developments in writing on the continent and in England. With true British bluntness, he did not fail to speak his mind, never hesitated to draw discriminating comparisons where they were to be drawn, and criticised novelists to his own taste, utterly disregarding their pecuniary value to the publisher.

Where merit was to be found, praise was awarded as generously as it was withheld in other quarters. Personalities were in order, for Pollard's theory was that "denouncing a crime against literature has never seemed to me as efficacious, or so honest, as denouncing the criminal."17 So he paved the way for the verbal fisticuffs that later critics used as their chief stock-in-trade. Since he smote most of the popular novelists of the time, he made the requisite number of enemies among them and their publishers.

This belligerency was a tonic dose for American letters. Nothing could have roused things better than the bitter vials of criticism that Pollard poured down the throats of complacent writers; nothing could have resurrected the literary consciousness of the time more than the violent purgatives he administered. For all the ephemerality of his work and the little of it which is preserved in book form, his was an active and dominating influence in the first decade of this century. So that it is as a gentleman of taste, of competent and authoritative judgment, of sincere and unfailing enthusiasm for the best in life and art, that Percival Pollard, obscure as he now is, exerted a beneficent influence on the course of American writing.

16 Current Literature, Vol. 52 (1912), pp. 339-340.

17 Pollard, Their Day in Court, p. 13. 